\title{
The role of chlorite dehydration in ultramafic rocks for slab melting and element recycling in subducted crust
}

\author{
JÖRG HERMANN ${ }^{1}$, SHAYNE LAKEY ${ }^{2}$, MATTHIAS \\ LEDERER $^{1}$ AND PROF. DANIELA RUBATTO ${ }^{3,4}$ \\ ${ }^{1}$ University of Bern \\ ${ }^{2}$ The Australian National University \\ ${ }^{3}$ University of Lausanne \\ ${ }^{4}$ University of Bern, Institute of Geological Sciences \\ Presenting Author: joerg.hermann@geo.unibe.ch
}

Chlorite-rich ultramafic rocks that formed at the slab-mantle interface are an important carrier of $\mathrm{H}_{2} \mathrm{O}$ to the subarc region. Piston cylinder experiments indicate that dehydration of chlorite harzburgite and chlorite schist occur at $850-720^{\circ} \mathrm{C}, 80-150 \mathrm{~km}$ depth, liberating 1-12 wt $\% \mathrm{H}_{2} \mathrm{O}$ depending on the amount of chlorite. Chlorite is the most stable hydrous phase with a high modal abundance in ultramafic rocks and thus a key player in fluid-mediated element recycling in subduction zones. No wet melting of chlorite schist has been observed at the conditions of chlorite dehydration. However, associated crustal rocks will undergo fluid-fluxed melting. Estimated P-T conditions for the extraction of slab fluids, based on the composition of the subduction component in arc lavas, overlap with the experimentally determined chlorite dehydration reactions, indicating a prominent role of chlorite in element recycling in subduction zones. Dehydration of chlorite-rich rock types leads to the formation of garnet-rich residues that are denser than the surrounding mantle. This renders chlorite-rich mélange rocks unsuitable as drivers for slab diapirs.

The experimental study is compared to eclogite-facies maficultramafic rocks from the Central Alps, (Switzerland), where fluids released from the breakdown of chlorite in peridotites triggered partial melting in the associated eclogites at conditions of $800 \pm 60{ }^{\circ} \mathrm{C}$ and $3.0 \pm 0.3 \mathrm{GPa}$. Leucosomes in eclogites consist of quartz, plagioclase and clinozoisite, are rich in $\mathrm{SiO}_{2}$, $\mathrm{Al}_{2} \mathrm{O}_{3}$ and $\mathrm{CaO}$ and display elevated $\mathrm{Pb}, \mathrm{U}, \mathrm{Th}, \mathrm{Sr}$ and LREE similar to the 'subduction component' in arc lavas. Partial melting produced multiple overgrows on igneous zircon cores that are characterized by low HREE without negative Eu anomaly, indicating formation under eclogite facies conditions. SIMS dating of these rims indicates that peak eclogite conditions and partial melting occurred around $32.0 \pm 1.0 \mathrm{Ma}$. The timing and high temperature of eclogite facies metamorphism suggest that the unit was situated at the transition of the subducted European margin that was affected by slab break off, offering the opportunity to study subducted oceanic crust at typical sub-arc conditions. 